Article

\title{
Determinants of Behavioral Intention to Use South Korean Airline Services: Effects of Service Quality and Corporate Social Responsibility
}

\section{Eunil Park ${ }^{1}$, Sanghoon Lee ${ }^{1}$, Sang Jib Kwon ${ }^{2, *}$ and Angel P. del Pobil ${ }^{3,4, *}$}

1 School of Innovation, Korea Advanced Institute of Science and Technology (KAIST), 291 Daehak-ro, Yuseong-gu, Daejeon 305-701, Korea; E-Mails: pa1324@kaist.ac.kr (E.P.); 1sh1221@kaist.ac.kr (S.L.)

2 Department of Business Administration, Dongguk University, 123 Dongdae-ro, Gyeongju-si, Gyeongsangbuk-do 780-714, Korea

3 Robotic Intelligence Laboratory, Department of Computer Science and Engineering, Jaume-I University, Edifici TI, Castellon de la Plana 12071, Spain

4 Department of Interaction Science, Sungkyunkwan University, 25-2 Sungkyunkwan-ro, Seoul 110-745, Korea

* Authors to whom correspondence should be addressed; E-Mails: risktaker@dongguk.ac.kr (S.J.K.); pobil@uji.es (A.P.P.); Tel.: +82-54-770-2357 (S.J.K.); +34-964-72-82-93 (A.P.P.); Fax: +82-2-770-2001 (S.J.K.); +34-964-72-84-86 (A.P.P.).

Academic Editor: Marc A. Rosen

Received: 10 July 2015 / Accepted: 20 August 2015 / Published: 1 September 2015

\begin{abstract}
Since the introduction of corporate social responsibility (CSR), it has become an important duty of companies and organizations. In addition, academic and industry researchers have attempted to explore the effects of corporate social responsibility on firm performance. To this end, this study examined how corporate social responsibility and service quality are notably associated with customer satisfaction and behavioral intention to use by employing a structural equation modeling method. A research model with nine constructs was introduced and the findings revealed that economic, social, and environmental responsibility, as well as in-flight service quality, significantly determined customer satisfaction, while there were notable connections between customer satisfaction and behavioral intention to use. However, service quality at airports did not have a significant effect on satisfaction. The practical and theoretical implications of the current study are discussed.
\end{abstract}


Keywords: corporate social responsibility; service quality; satisfaction; airline service; behavioral intention to use

\section{Introduction}

With the increasing focus on corporate social responsibility (CSR) in corporate sustainable management over the past several decades, many studies on the impact or benefits of CSR have been conducted in the academic fields of marketing and consumer behavior [1-3]. The relationship between CSR and customer perceptions and behaviors has become an important research topic because customer behaviors are closely related to the competitive advantages of firms in competitive markets $[4,5]$.

Among these, the behavioral intention (BI) of customers is also recognized as a significant determinant of the profitability and success of firms in the service sector [6-8]. Therefore, many researchers have investigated which determinants affect customer behaviors such as satisfaction, loyalty, and intentions in various service industries, including lodging [9], auditing [10], banking [11], e-services [12], and hotels and restaurants [13].

With regard to airline services in particular, previous studies have aimed to identify the determinants of BI $[14,15]$. As it is among the most critical success factors related to the profitability and performance of airline service firms, many studies have focused on the influence of service quality (SQ) on BI [16]; however, CSR initiatives are still not regarded as important factors of business success in the airline industry. As a result, the understanding of the impact of CSR on customer behavior in airline services is still limited and few empirical studies have been conducted on the importance on both CSR and SQ.

Therefore, the concepts of CSR and SQ are treated as important determinants of customer behaviors in this study. The purpose of this study is to examine the effects of two determinants, CSR and SQ, on consumers' perceptions and behaviors (BI) and investigate the mediating effect of CS between CSR/SQ and BI in South Korean airline services. That is, CSR and SQ affect customer satisfaction (CS), which, in turn, influences BI; in other words, the proposed research model can be logically expected to find that CS plays a mediating role in the CSR/SQ-BI relation.

The remainder of this study is organized as follows. Section 2 presents a review of the literature on CSR, SQ, and BI and proposes the research hypotheses. Section 3 explains the research model and describes the employed methodology. Section 4 explores the results of the structural equation model. Finally, Section 5 concludes with a summary of the major findings and implications, while limitations and directions for further research are presented in Section 6.

\section{Literature Review and Hypotheses}

\subsection{Corporate Social Responsibility}

The concept of corporate social responsibility (CSR) has emerged as a societal obligation in business during the last decades and has been the subject of many studies conducted in various academic fields with regard to different perspectives and aspects $[17,18]$. From the viewpoint of corporate 
sustainable management, the sustainable development of CSR activities is an especially-important issue as a new paradigm of strategic management.

In general, many researchers have investigated the benefits of CSR on customer behavior $[2,3,19,20]$, and identified how the CSR initiatives or programs of firms lead various factors of customer impact or responses, including loyalty, word of mouth, and intention [21-23]. Handleman and Arnold [22] and Szymanski and Jenard [24] found a direct positive relationship between CSR and word of mouth, while Bolton and Drew [25] and Maignan and Ferrell [1] indicated that CSR is a direct determinant of customer loyalty.

Moreover, CS has been recognized as an important factor of corporate profitability and market value [26,27], and a few scholars have focused on the research relevant to the association between CSR and CS [11,28,29]. CRS initiatives have a direct positive impact on CS [13,28], while CS has mediated between CSR and firm market value [28]. According to Senthikumar and colleagues [11], CSR is the most influential determinant of CS.

This study concentrates on CSR as one of the important determinants of CS in the airline industry and CSR is divided into the three dimensions of the "tripe-bottom-line" concept: economic, environmental, and social capital [30,31]. In addition, we suggest that dissatisfaction is the major reason that customers change airlines and believe that the three different types of CSR initiatives (economic, environmental, and social) will lead to improved customer satisfaction in airline services. Therefore, we propose the following hypotheses:

H1. Economic responsibility is positively associated with consumer satisfaction.

$\mathrm{H} 2$. Social responsibility is positively associated with consumer satisfaction.

H3. Environmental responsibility is positively associated with consumer satisfaction.

\subsection{Service Quality}

Service quality (SQ) has been recognized as an important factor that leads to the differentiation of services and products and the achievement of competitive advantages [32,33]; in particular, it is closely related to firm profitability and performance in the service sector [16]. SQ is defined as the perceived quality of services that customers have received and can be evaluated by customers' experiences of services compared to their expectations [34-36].

Many studies have investigated the effects of SQ on consumer behaviors, such as CS, customer loyalty, and behavioral intentions, as well as on firm performance, in various service industries [14,37-39] and found it to have a positive impact [37,40]. Lee and Cunningham [37] indicated that service quality perceptions have a positive impact on service loyalty in banks and travel agencies, while Santos [12] found that high E-service quality provides long-term benefits to companies in the E-commerce industry. Moreover, Cronin and Taylor [41] investigated the relationships among SQ, CS, and purchase intentions and found that SQ is an antecedent of CS and that CS has a positive impact on purchase intentions in four service industries: banking, pest control, dry cleaning, and fast food. Based on the findings of prior studies on service quality, service quality is considered as one of the critical antecedents in improving service competitiveness [15].

In addition, many previous studies have identified the different factors of SQ that influence consumer behavior in the airline industry. The results of Saha and Theingi [39] indicated that 
schedule-related SQ has the greatest influence on CS among Thai low-cost carriers, whereas An and Noh [14] point out that different factors of SQ affect CS according to customer seat class. Park and colleagues [42] found that three factors of SQ (service value, passenger satisfaction, and airline image) have a significant effect on the BI of passengers. Moreover, Namukasa [38] emphasized that SQ, including pre-flight, in-flight, and post-flight services, has a positive influence on CS.

Due to the fact that customers' expectations of airline service quality vary at different phases of the service chain process, this study classified SQ into two distinct dimensions: in-flight and ground airport [43]. We expect that the two different types of SQ will have effects on improving customer satisfaction in airline services. Thus, we propose the following hypotheses:

H4. In-flight service quality is positively associated with customer satisfaction.

H5. Service quality at airports is positively associated with customer satisfaction.

\subsection{Customer Satisfaction and Behavioral Intention to Use}

In corporate strategy, customer satisfaction (CS) is an important determinant of business success. Many studies have found that CS leads to improved customer loyalty as well as greater company profitability and performance [44-53]. Reichheld and Sasser [7] indicated that retaining customers with higher CS has a greater impact on firm profitability than obtaining new customers.

Moreover, CS is the most important determinant of BI, which is an indicator of customers' subjective behaviors and how they make consumption decisions. BI is measured through several factors such as word-of mouth communications, repurchase intentions, price sensitivity, loyalty, complaints, and willingness to pay [33]. Zeithaml and colleagues [33] divided BI into two dimensions: favorable (word-of mouth communications, purchase intentions, and price sensitivity) and unfavorable (complaints).

In this study, BI is composed of three dimensions: intention to re-visit [41], word of mouth [39], and willingness to pay [54,55]. Many studies have found that there is a positive relationship between CS and repurchase intention [56,57]. Other studies have found a direct positive relationship between CS and word of mouth [58-61] and indicated that CS also has a positive effect on firm profitability by virtue of new recommendations through positive word of mouth [62]. Moreover, satisfied customers tend to accept and be willing to pay premium prices [63].

Based on previous literature, we believe that CS will lead to improvements in the three different types of BI (intention to re-visit, word of mouth, and willingness to pay) in airline services. Therefore, we propose the following hypotheses:

H6. Customer satisfaction is positively associated with intention to re-visit.

H7. Customer satisfaction is positively associated with word of mouth.

H8. Customer satisfaction is positively associated with willingness to pay.

\subsection{The Research Model}

The research model, based on the provided hypotheses, is introduced in Figure 1. 


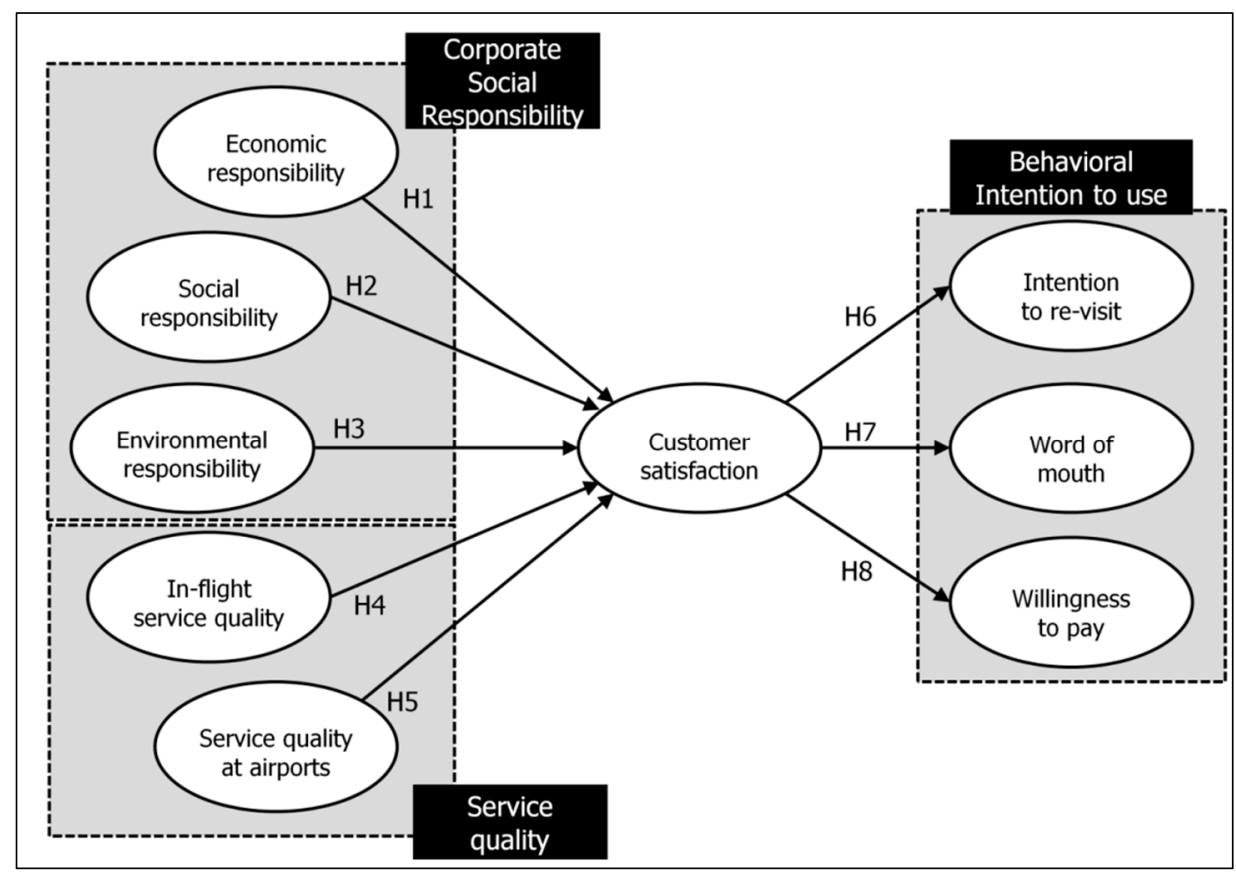

Figure 1. The proposed research model.

\section{Study Method}

\section{Survey Design}

A quantitative method was used to test the introduced hypotheses. A total of 1311 questionnaires were distributed in three South Korean international airports: the Gimpo, Gimhae, and Incheon airports. A convenience sampling method showed that 1189 samples were usable, with a 90.7\% validated response rate. All respondents were South Koreans who had used the same airlines more than three times. The survey was organized into three sections. The first section, covering the first two pages, asked demographic-related questions including age, gender, and level of education. The second section contained questionnaire items on the service experiences of the respondents, including their primary airline service provider and the number of flying experiences with the currently used airline. The third section of the survey consisted of measurement items on eight employed factors. In this section, all questionnaire items were validated by previous studies, while three professors and two researchers in the communications and service industries reviewed and revised the 32 items collected initially. After conducting two-round pretests with 25 respondents, the final survey contained 23 questionnaire items (Table 1). Two professional statistical tools, SPSS 20 and AMOS 18.0, were used in testing the research model.

Table 1. Questionnaire items in the survey.

\begin{tabular}{ll}
\hline \multicolumn{1}{c}{ Factors } & \multicolumn{1}{c}{ Descriptions } \\
\hline & ECR1: This airline makes an effort to contribute to society and the economy by investing and \\
& generating profits. \\
Economic responsibility & ECR2: This airline makes an effort to create new jobs. \\
{$[1,64,65]$} & ECR3: This airline makes an effort to contribute to national economic development by \\
& creating more value. \\
\hline
\end{tabular}


Table 1. Cont.

\begin{tabular}{ll}
\hline \multicolumn{1}{c}{ Factors } & \\
\hline $\begin{array}{l}\text { Social responsibility } \\
{[1,64,65]}\end{array}$ & $\begin{array}{l}\text { SR1: This airline makes an effort to raise funds for social causes. } \\
\text { SR2: This airline encourages its employees to participate in volunteer activities in local } \\
\text { communities. } \\
\text { SR3: This airline supports sporting and cultural events. }\end{array}$ \\
\hline Environmental & ENR1: This airline makes an effort to participate in environmental campaigns. \\
responsibility & ENR2: This airline makes an effort to reduce waste and use environmentally friendly products. \\
[1,64,65] & ENR3: This airline uses energy and resources efficiently. \\
\hline In-flight service quality & ISQ1: Employees provide prompt service in the airplane. \\
[66,67] & ISQ2: Employees are always willing to help in the airplane. \\
\hline Service quality at airports & SQQ3: Employees are friendly and courteous in the airplane. \\
\hline 66,67] & SQA2: Employees of this airline provide prompt service at airports. \\
\hline & SQA3: Employees of this airline are friendly and courteous at airports. \\
\hline Customer satisfaction [68] & CS1: I feel happy after flying with this airline. \\
& CS3: I feel satisfied after using this airline. \\
\hline Intention to re-visit & IR1: I am willing to use this airline. \\
I67,69,70] & $\begin{array}{l}\text { IR2: I will consider reusing this airline in the future. } \\
\text { IR3: If I need to fly in the future, I will choose the current airline. }\end{array}$ \\
\hline Word of mouth [69] & WM1: I encourage my friends and relatives to use this airline. \\
\hline Willing to pay [71,72] & WP1: If I have the choice, I will continue to use the current airline even if it is more expensive. \\
\hline
\end{tabular}

\section{Results}

The measurement and structural models used two-step structural equation modeling methods to examine the reliability of the constructs and explore the structural connections between them. In addition, the maximum likelihood method was used to determine the validity of the constructs.

The demographic information of the survey respondents is shown in Table 2 . More than $50 \%$ of the respondents had a bachelor degree or above, while $50.8 \%$ were male.

Table 2. Demographic information of survey participants.

\begin{tabular}{|c|c|c|c|c|c|}
\hline & Factors & Values & & Factors & Values \\
\hline \multirow{3}{*}{ Gender } & \multirow{3}{*}{$\begin{array}{l}\text { Male } \\
\text { Female }\end{array}$} & \multirow{3}{*}{$\begin{array}{l}604(50.8 \%) \\
585(49.2 \%)\end{array}$} & \multirow{3}{*}{ Education } & High school & $317(26.7 \%)$ \\
\hline & & & & Undergraduate & $669(56.3 \%)$ \\
\hline & & & & Graduate or above & $203(16.3 \%)$ \\
\hline \multirow{8}{*}{ Age } & $18-25$ & $109(9.2 \%)$ & \multirow{4}{*}{ Monthly income } & Below 10,000 USD & $322(27.1 \%)$ \\
\hline & $26-35$ & $497(41.8 \%)$ & & $10,000 \sim 20,000$ USD & $495(41.6 \%)$ \\
\hline & $36-45$ & $332(27.9 \%)$ & & $20,000 \sim 30,000$ USD & $203(17.1 \%)$ \\
\hline & Above 46 & $251(21.1 \%)$ & & Above 30,000 USD & $194(16.3 \%)$ \\
\hline & & & \multirow{4}{*}{$\begin{array}{l}\text { Flying experience of } \\
\text { the current airline }\end{array}$} & $3 \sim 5$ times & $186(15.6 \%)$ \\
\hline & & & & $5 \sim 10$ times & $642(54.0 \%)$ \\
\hline & & & & 10 15 times & $224(18.8 \%)$ \\
\hline & & & & Over 15 times & $137(11.5 \%)$ \\
\hline
\end{tabular}




\subsection{Descriptive Analyses and Measurement Validity}

Table 3 shows the descriptive statistics of the constructs. In general, customers exhibited positive responses to the constructs (over 4.0; Table 3). The tests of the internal reliability, convergent reliability (Table 4), and discriminant validity (Table 5) of the constructs were conducted. Considering the recommended standards, which are Cronbach's alpha and factor loading values greater than 0.7 and composite reliability and average variance extracted values greater than 0.5 , the current data showed great internal and convergent validity.

Table 3. Descriptive statistics.

\begin{tabular}{cccccc}
\hline Factors & Mean & Standard Deviation & Factors & Mean & Standard Deviation \\
\hline Economic responsibility & 4.94 & 1.14 & Customer satisfaction & 5.11 & 1.12 \\
Social responsibility & 4.98 & 1.20 & Intention to re-visit & 5.10 & 1.04 \\
Environmental responsibility & 4.89 & 1.22 & Word of mouth & 4.71 & 1.04 \\
In-flight service quality & 5.38 & 1.12 & Willingness to pay & 5.01 & 1.06 \\
Service quality at airports & 5.09 & 1.08 & & & \\
\hline
\end{tabular}

Table 4. The internal and convergent validity.

\begin{tabular}{|c|c|c|c|c|c|}
\hline \multirow[b]{2}{*}{ Factors } & \multicolumn{2}{|c|}{ Internal Reliability } & \multicolumn{3}{|c|}{ Convergent Reliability } \\
\hline & $\begin{array}{c}\text { Cronbach's } \\
\text { Alpha }\end{array}$ & $\begin{array}{l}\text { Item-Total } \\
\text { Correlation } \\
\end{array}$ & $\begin{array}{c}\text { Factor } \\
\text { Loading }\end{array}$ & $\begin{array}{l}\text { Composite } \\
\text { Reliability }\end{array}$ & $\begin{array}{c}\text { Average Variance } \\
\text { Extracted }\end{array}$ \\
\hline \multirow{3}{*}{ Economic responsibility } & \multirow{3}{*}{0.759} & 0.729 & 0.724 & \multirow{3}{*}{0.866} & \multirow{3}{*}{0.686} \\
\hline & & 0.736 & 0.914 & & \\
\hline & & 0.799 & 0.835 & & \\
\hline \multirow{3}{*}{ Social responsibility } & \multirow{3}{*}{0.810} & 0.816 & 0.914 & \multirow{3}{*}{0.894} & \multirow{3}{*}{0.739} \\
\hline & & 0.798 & 0.912 & & \\
\hline & & 0.791 & 0.742 & & \\
\hline \multirow{3}{*}{$\begin{array}{l}\text { Environmental } \\
\text { responsibility }\end{array}$} & \multirow{3}{*}{0.882} & 0.794 & 0.916 & \multirow{3}{*}{0.928} & \multirow{3}{*}{0.812} \\
\hline & & 0.775 & 0.919 & & \\
\hline & & 0.785 & 0.868 & & \\
\hline \multirow{3}{*}{ In-flight service quality } & \multirow{3}{*}{0.902} & 0.765 & 0.904 & \multirow{3}{*}{0.939} & \multirow{3}{*}{0.837} \\
\hline & & 0.718 & 0.911 & & \\
\hline & & 0.782 & 0.929 & & \\
\hline \multirow{3}{*}{ Service quality at airports } & \multirow{3}{*}{0.882} & 0.767 & 0.862 & \multirow{3}{*}{0.927} & \multirow{3}{*}{0.810} \\
\hline & & 0.774 & 0.917 & & \\
\hline & & 0.779 & 0.919 & & \\
\hline \multirow{3}{*}{ Customer satisfaction } & \multirow{3}{*}{0.889} & 0.704 & 0.855 & \multirow{3}{*}{0.932} & \multirow{3}{*}{0.822} \\
\hline & & 0.739 & 0.943 & & \\
\hline & & 0.846 & 0.919 & & \\
\hline \multirow{3}{*}{ Intention to re-visit } & \multirow{3}{*}{0.950} & 0.880 & 0.853 & \multirow{3}{*}{0.889} & \multirow{3}{*}{0.728} \\
\hline & & 0.844 & 0.860 & & \\
\hline & & 0.865 & 0.847 & & \\
\hline Word of mouth & - & - & - & - & - \\
\hline Willingness to pay & - & - & - & - & - \\
\hline
\end{tabular}


Table 5. Discriminant reliability.

\begin{tabular}{lccccccccc}
\hline \multicolumn{1}{c}{ Factors } & $\mathbf{1}$ & $\mathbf{2}$ & $\mathbf{3}$ & $\mathbf{4}$ & $\mathbf{5}$ & $\mathbf{6}$ & $\mathbf{7}$ & $\mathbf{8}$ & $\mathbf{9}$ \\
\hline 1. Economic responsibility & 0.83 & & & & & & & \\
2. Social responsibility & 0.43 & 0.86 & & & & & & \\
3. Environmental responsibility & 0.32 & 0.41 & 0.90 & & & & & \\
4. In-flight service quality & 0.22 & 0.47 & 0.53 & 0.91 & & & & \\
5. Service quality at airports & 0.23 & 0.32 & 0.33 & 0.26 & 0.90 & & & \\
6. Customer satisfaction & 0.30 & 0.36 & 0.26 & 0.19 & 0.27 & 0.91 & & \\
7. Intention to re-visit & 0.20 & 0.30 & 0.33 & 0.20 & 0.38 & 0.42 & 0.85 & & \\
8. Word of mouth & 0.42 & 0.14 & 0.43 & 0.26 & 0.25 & 0.26 & 0.41 & - & \\
9. Willingness to pay & 0.36 & 0.44 & 0.38 & 0.24 & 0.37 & 0.14 & 0.23 & 0.40 & - \\
\hline
\end{tabular}

Note: The square root values of average variance extracted are presented in diagonal positions.

Moreover, the square root values of the average variance extracted should be higher than the shared correlation values between the constructs. As shown in Table 5, the current study also met the guidelines for discriminant validity.

\subsection{Fit Indices of the Measurement Model}

Table 6 presents the fit indices of the measurement model; the indices were generally accepted by satisfying the recommended values suggested by previous studies.

Table 6. Fit indices of the measurement model [73-77].

\begin{tabular}{ccc}
\hline Fit Indices & The Measurement Model & Recommended Level \\
\hline Chi-square/d.f. & 4.77 & $<5.00$ \\
Goodness of Fit Index (GFI) & 0.826 & $>0.800$ \\
Parsimony Goodness of fit index (PGFI) & 0.541 & $>0.500$ \\
Normed Fit Index (NFI) & 0.844 & $>0.800$ \\
Relative Fit Index (RFI) & 0.864 & $>0.800$ \\
Incremental Fit Index (IFI) & 0.913 & $>0.900$ \\
Comparative Fit Index (CFI) & 0.950 & $>0.900$ \\
Parsimony Comparative Fit Index (PCFI) & 0.756 & $>0.500$ \\
Parsimony Normed Fit Index (PNFI) & 0.720 & $>0.500$ \\
Root Mean Square Error of Approximation (RMSEA) & 0.075 & $<0.080$ \\
\hline
\end{tabular}

\subsection{Hypotheses Tests}

The structural connections were evaluated and examined by using the structural equation modeling method and showing the fit indices and coefficient estimations. The research model exhibited good fit (Table 7).

Table 7. Fit indices of the research model [73-77].

\begin{tabular}{ccc}
\hline Fit Indices & The Research Model & Recommended Level \\
\hline Chi-square/d.f. & 4.94 & $<5.00$ \\
Goodness of Fit Index (GFI) & 0.852 & $>0.800$ \\
\hline
\end{tabular}


Table 7. Cont.

\begin{tabular}{ccc}
\hline Fit Indices & The Research Model & Recommended Level \\
\hline Parsimony Goodness of fit index (PGFI) & 0.583 & $>0.500$ \\
Normed Fit Index (NFI) & 0.885 & $>0.800$ \\
Relative Fit Index (RFI) & 0.805 & $>0.800$ \\
Incremental Fit Index (IFI) & 0.902 & $>0.900$ \\
Comparative Fit Index (CFI) & 0.942 & $>0.900$ \\
Parsimony Comparative Fit Index (PCFI) & 0.712 & $>0.500$ \\
Parsimony Normed Fit Index (PNFI) & 0.706 & $>0.500$ \\
Root Mean Square Error of Approximation (RMSEA) & 0.073 & $<0.080$ \\
\hline
\end{tabular}

Figure 2 and Table 8 summarize the results of the structural model by showing the extent of the direct relationships between the constructs. Interestingly, service quality at airports was not significantly associated with customer loyalty $(\beta=0.055, p>0.05)$, suggesting that H5 was not supported. However, in-flight service quality was found to be one of the notable determinants of customer satisfaction $(\beta=0.286, p<0.001$ ), supporting H4. Among the three subjective types of CSR, economic responsibility had the strongest effect on customer satisfaction $(\mathrm{H} 1, \beta=0.378, p<0.001)$, while the social $(\mathrm{H} 2, \beta=0.171, p<0.001)$ and environmental responsibilities $(\mathrm{H} 3, \beta=0.188, p<0.001)$ also significantly affected customer satisfaction. With the validation of these hypotheses, $88.2 \%$ of the variance in customer satisfaction was elucidated by the three types of corporate social responsibility and in-flight service quality. All of the hypotheses on the influence of customer satisfaction on behavioral intention to use were supported (H6, H7, and H8). Customer satisfaction had notable effects on intention to re-visit (H6, $\beta=0.829, p<0.001$ ), word of mouth $(\mathrm{H} 7, \beta=0.709, p<0.001)$, and willingness to pay (H8, $\beta=0.794, p<0.001)$. Moreover, $68.8 \%$ of the variance in intention to re-visit was explained by customer satisfaction.

Table 8. Summary of the research model ( $* p<0.001)$.

\begin{tabular}{lcccc}
\hline \multicolumn{1}{c}{ Hypotheses } & Standardized Coefficient & SE & CR & Results \\
\hline $\begin{array}{l}\text { H1. Economic responsibility } \\
\rightarrow \text { Customer satisfaction }\end{array}$ & $0.378^{*}$ & 0.052 & 8.482 & Supported \\
\hline $\begin{array}{l}\text { H2. Social responsibility } \\
\rightarrow \text { Customer satisfaction }\end{array}$ & $0.171^{*}$ & 0.030 & 5.745 & Supported \\
\hline $\begin{array}{l}\text { H3. Environmental responsibility } \\
\rightarrow \text { Customer satisfaction }\end{array}$ & $0.188^{*}$ & 0.026 & 5.339 & Supported \\
\hline $\begin{array}{l}\text { H4. In-flight service quality } \\
\rightarrow \text { Customer satisfaction }\end{array}$ & $0.286^{*}$ & 0.030 & 8.422 & Supported \\
\hline $\begin{array}{l}\text { H5. Service quality at airports } \\
\rightarrow \text { Customer satisfaction }\end{array}$ & 0.055 & 0.035 & 1.392 & Not Supported \\
\hline $\begin{array}{l}\text { H6. Customer satisfaction } \\
\rightarrow \text { Intention to re-visit }\end{array}$ & $0.829^{*}$ & 0.052 & 26.003 & Supported \\
\hline $\begin{array}{l}\text { H7. Customer satisfaction } \\
\rightarrow \text { Word of mouth }\end{array}$ & $0.709^{*}$ & 0.041 & 23.527 & Supported \\
\hline $\begin{array}{l}\text { H8. Customer satisfaction } \\
\rightarrow \text { Willingness to pay }\end{array}$ & $0.794^{*}$ & 0.051 & 26.639 & Supported \\
\hline
\end{tabular}




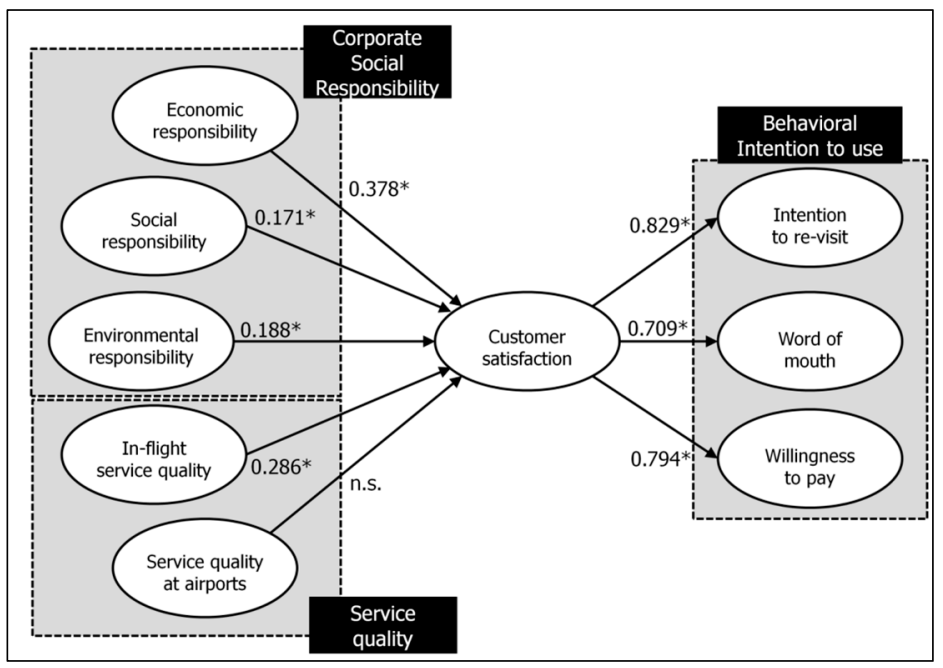

Figure 2. The results of the research model $(* p<0.001)$.

With regard to the standardized total effects of the two types of service quality and three subjective types of corporate social responsibility on intention to re-visit, economic responsibility showed the greatest impact on this intention (0.313).

\subsection{Supplemental Analysis}

The present study performed additional SEM analyses based on gender, age, monthly income, flying experience of the current airline, and education level, in order to investigate whether the structural connections of the research model were similar or different across the subjective features of the survey participants. Results showed that the majority of subjective groups presented similar patterns of the results of the research model, compared to the results of the whole group.

\section{Discussion and Conclusions}

The purpose of this study was to investigate whether and how service quality and CSR significantly affect behavioral intention to use through customer satisfaction among South Korean airline service providers by exploring an integrated research model. The results of structural equation modeling supported seven hypotheses, while H5, regarding the relationship between service quality at airports and customer satisfaction, was not supported. As shown in the great degree of the variance in customer satisfaction (0.882), customer satisfaction serves as the bridge between CSR, service quality, and behavioral intention to use.

The results also showed that CSR has a significant effect on behavioral intention to use and satisfaction. Moreover, the great degrees of model fit strongly supported the research model. The bridge role played by customer satisfaction suggests that CSR and service quality activities could lead to improved customer satisfaction, leading customers to exhibit greater behavioral intention to use.

Among the three types of CSR, economic responsibility is the greatest antecedent of customer satisfaction. This may be related to the industrial and market conditions faced by South Korean airlines. Because the current South Korean airline service industry is regarded as one of the most 
mature and competitive markets and is mainly dominated by two large conglomerates, academic and industry researchers have consistently focused their efforts on how to attract more customers [78,79].

The insignificant relationship between service quality at airports and customer satisfaction (H5) could be explained by the specific characteristics of airline services. Although each airline service provider has its hub airport, many airlines share airports. For example, there are 94 airlines at Incheon international airport, 15 at Gimpo international airport, and 22 at Gimhae international airport. Therefore, the respondents did not consider the service quality of their current airlines to be related to service quality at airports, and rather determined their perceived service quality based on their in-flight experiences.

This study provides a better understanding of behavioral intention to use and customer satisfaction by examining the subjective dimensions of CSR and service quality among airline service providers. The findings also provide several theoretical and practical insights for airline marketers, managers, and researchers who want to understand how to increase customer behavioral intention to use. This study extends the basic knowledge of and insights into CSR, service quality, and behavioral intention to use by introducing the research model and using the structural equation modeling method.

The current study has several key findings. First, customer satisfaction is an important mediating construct affecting behavioral intention to use, and this should be considered in the provision of airline services. Second, the findings of the current study show that the in-flight service quality and CSR efforts of airline service providers are positively and directly related to customer satisfaction $[14,80]$. These findings are consistent with the results of previous studies on CSR and service quality [28,81-84]. Third, although four potential antecedents of customer satisfaction significantly affect customer satisfaction and indirectly influence behavioral intention to use, economic responsibility has the greatest effect on behavioral intention to use. This means that airline service providers should aim to contribute economically to society by creating new jobs and generating value [85].

\section{Limitations and Future Studies}

Despite the great fit of the introduced research model including CSR, SQ, CS, and BI, this study has some notable limitations. First, the data used in this study were collected in just one nation (South Korea). This means that the generalizability of the findings could potentially be questioned [86-89]. Second, this study did not consider low-cost airlines in South Korea, because the low-cost airline industry has a complex structure [90]. Therefore, future studies should examine other nations and more comprehensively explore the airline industry, including low-cost airlines.

\section{Acknowledgments}

This study was supported by the Dongguk University Research Fund of 2015. Support for the UJI Robotic Intelligence Laboratory is provided in part by Ministerio de Economíay Competitividad (DPI2011-27846), by Generalitat Valenciana (PROMETEOII/2014/028) and by Universitat Jaume I (P1-1B2014-52). 


\section{Author Contributions}

Sanghoon Lee and Eunil Park conducted the analyses and wrote the majority of the manuscript. Sang Jib Kwon and Angel P. del Pobil contributed to data collection and interpretation of data.

\section{Conflicts of Interest}

The authors declare no conflict of interest.

\section{References}

1. Maignan, I.; Ferrell, O.C. Corporate citizenship as a marketing instrument: Concepts, evidence and research directions. Eur. J. Mark. 2001, 35, 457-484.

2. Sen, S.; Bhattacharya, C.B. Does doing good always lead to doing better? Consumer reactions to corporate social responsibility. J. Mark. Res. 2001, 38, 225-243.

3. Sen, S.; Bhattacharya, C.B.; Korshun, D. The role of corporate social responsibility in strengthening multiple stakeholder relationships: A field experiment. J. Acad. Mark. Sci. 2006, 34, 158-166.

4. Kotler, P.; Armstrong, G. Principles of Marketing, 12th ed.; Prentice Hall: Upper Saddle River, NJ, USA, 2008.

5. Orel, F.; Kara, A. Supermarket self-checkout service quality, customer satisfaction, and loyalty: Empirical evidence from an emerging market. J. Retail. Consum. Serv. 2014, 21, 118-129.

6. Anderson, E.W.; Fornall, C.; Lehmann, D.R. Customer satisfaction, market share, and profitability: Findings from Sweden. J. Market. 1994, 58, 53-66.

7. Reichheld, F.F.; Sasser, W.E. Zero defections: Quality comes to services. Harv. Bus. Rev. 1990, 68, 105-112.

8. Slater, S.F.; Narver, J.C. Market orientation and the learning organization. J. Market. 1995, 59, 63-74.

9. Olorunniwo, F.; Hsu, M.K.; Udo, G. Service quality, customer satisfaction, and behavioural intentions in the service factory. J. Serv. Market. 2006, 20, 59-72.

10. Ismail, I.; Haron, H.; Ibrahim, D.N.; Isa, S.M. Service quality, client satisfaction and loyalty towards audit firms: Perceptions of Malaysian public listed companies. Manag. Audit. J. 2006, 21, 738-756.

11. Senthikumar, N.; Ananth, A.; Arulrah. A. Impact of corporate social responsibility on customer satisfaction in banking service. Afr. J. Bus. Manag. 2001, 5, 3028-3039.

12. Santos, J. E-service quality: A model of virtual service quality dimensions. Manag. Serv. Qual. 2003, 13, 233-246.

13. Lee, S.; Heo, C.Y. Corporate social responsibility and customer satisfaction among US publicly traded hotels and restaurants. Int. J. Hosp. Manag. 2009, 28, 635-637.

14. An, M.; Noh, Y. Airline customer satisfaction and loyalty: Impact of in-flight service quality. Serv. Bus. 2009, 3, 293-307.

15. Baker, D. Service quality and customer satisfaction in the airline industry: A comparison between legacy airlines and low-cost airlines. Am. J. Tour. Res. 2013, 2, 67-77. 
16. Heskett, J.L.; Jones, T.O.; Loveman, G.W.; Sasser, W.E.; Schlesinger, L.A. Putting the service profit chain to work. Harv. Bus. Rev. 1994, 72, 105-111.

17. Brown, T.J.; Dacin, P.A. The company and the product: Corporate associations and consumer product responses. J. Market. 1997, 61, 68-84.

18. Kotler, P.; Lee, N. Corporate Social Responsibility; Wiley: Hoboken, NJ, USA, 2005.

19. Drumwright, M.E. Company advertising with a social dimension: The role of non-economic criteria. J. Market. 1996, 60, 71-86.

20. Murray, K.B.; Vogel, C.M. Using a hierarchy-of-effects approach to gauge the effectiveness of corporate social responsibility to generate goodwill toward the firm: Financial versus non-financial impacts. J. Bus. Res. 1997, 38, 141-159.

21. Maignan, I.; Ferrell, O.C. Corporate social responsibility and marketing: An integrative framework. J. Acad. Market. Sci. 2004, 32, 3-19.

22. Handleman J.M.; Arnold, S.J. The role of marketing actions with a social dimension: Appeals to the institutional environment. J. Market. 1999, 63, 38-48.

23. Maignan I.; Ferrell, O.; Hult, G. Corporate citizenship: Culture antecedents and business benefits. J. Acad. Market. Sci. 1999, 27, 455-469.

24. Szymanski, D.M.; Henard, D. Customer satisfaction: A meta-analysis of the empirical evidence. J. Acad. Market. Sci. 2001, 29, 16-35.

25. Bolton, R.N.; Drew, J.H. A multistage model of consumer feelings and purchase likelihood. Psychol. Market. 1991, 9, 347-363.

26. Fornell, C.; Mithas, S.; Morgenson, F.V.; Krishnan, M.S. Customer satisfaction and stock prices: High returns, low risk. J. Market. 2006, 70, 1-14.

27. Gruca, T.S.; Rego, L.L. Customer satisfaction, cash flow and shareholder value. J. Market. 2005, 69, 115-130.

28. Lou, X.; Bhattacharya, C.B. Corporate social responsibility, customer satisfaction and market value. J. Market. 2006, 70, 1-18.

29. Lynette, M.; Sharyn, R. Corporate social responsibility and bank customer satisfaction: A research agenda. Int. J. Bank Market. 2008, 26, 170-182.

30. Dyllick, T.; Hockerts, K. Beyond the business case for corporate sustainability. Bus. Strategy Environ. 2002, 11, 130-141.

31. Elkington, J. Cannibals with Forks: The Triple Bottom Line of 21st Century Business; New Society: Stony Creek, CT, USA, 1997.

32. Ennew, C.T.; Reed, G.V.; Binks, M.R. Importance-performance analysis and the measurement of service quality. Eur. J. Market. 1993, 27, 59-70.

33. Zeithaml, V.A.; Berry, L.L.; Parasuraman, B.A. The behavioral consequences of service quality. J. Market. 1996, 60, 31-46.

34. Garvin, D. What does "product quality" really mean. Sloan Manag. Rev. 1984, 26, $24-43$.

35. Gronroos, C. A service quality model and its marketing implication. Eur. J. Market. 1984, 18, 36-44.

36. Lewis, R.C.; Booms, B.H. The Marketing aspects of service quality. In Emerging Perspectives on Services Marketing; Berry, L., Shostack, G., Upah, G., Eds.; American Marketing: Chicago, MA, USA, 1983; pp. 99-107. 
37. Lee M.; Cunningham, L. A cost/benefit approach to understanding service loyalty. J. Serv. Market. 2001, 15, 113-130.

38. Namukasa, J. The influence of airline service quality on passenger satisfaction and loyalty: The case of Uganda airline industry. TQM J. 2013, 25, 520-532.

39. Saha, G.C.; Theingi. Service quality, satisfaction, and behavioural intentions: A study of low-cost airline carriers in Thailand. Manag. Serv. Qual. 2009, 19, 350-375.

40. Ostrowski, P. Service quality and customer loyalty in the commercial airline industry. J. Travel Res. 1993, 32, 16-24.

41. Cronin J.J.; Taylor, S. Measuring service quality: A re-examination and extension. J. Market. 1992, 56, 55-68

42. Park, J.W.; Robertson, R.; Wu, C.L. The effects of airline service quality on passenger's behavioural intentions: A Korean case study. J. Air Transp. Manag. 2004, 10, 435-439.

43. Chen, F.; Chang, Y. Examining airline service quality from a process perspective. J. Air Transp. Manag. 2005, 11, 79-87.

44. Anderson, E.W.; Sullivan, M.W. The antecedents and consequences of customer satisfaction firms. Market. Sci. 1993, 12, 241-268.

45. Bearden, W.O.; Teel, J.E. Selected determinants of consumer satisfaction and complaint reports. J. Market. Res. 1983, 20, 21-28.

46. Bolton, R.N.; Drew, J.H. A longitudinal analysis of the impact of service changes on customer attitudes. J. Market. 1991, 55, 1-9.

47. Bolton, R.N.; Drew, J.H. A multistage model of customers' assessments of service quality and value. J. Consum. Res. 1991, 17, 375-384.

48. Fornell, C. A national customer satisfaction barometer: The Swedish experience. J. Market. 1992, $56,6-21$.

49. LaBarbera, P.A.; Mazursky, D. A longitudinal assessment of consumer satisfaction, dissatisfaction: The dynamic aspect of cognitive process. J. Market. Res. 1983, 20, 393-404.

50. Oliver, R.L. A cognitive model of the antecedents and consequences of satisfaction decision. J. Market. Res. 1980, 17, 460-469.

51. Oliver, R.L.; Swan, J.E. Consumer perceptions of interpersonal equity and satisfaction in transactions: A field survey approach. J. Market. 1989, 53, 21-35.

52. Oliver, R.L.; Swan, J.E. Equity and disconfirmation perceptions as influences on merchant and product satisfaction. J. Consum. Res. 1989, 16, 372-383.

53. Reichheld, F.F.; Teal, T. The Loyalty Effect: The Hidden Force behind Growth, Profits, and Lasting Value. Harvard Business Press: Boston, MA, USA, 2001.

54. Cameron, T.A.; James, M.D. Estimating willingness to pay from survey data: An alternative pre-test-market evaluation procedure. J. Market. Res. 1987, 24, 389-395.

55. Hanemann, W.M. Willingness to pay and willingness to accept: How much can they differ? Am. Econ. Rev. 1991, 81, 635-647.

56. Bitner, M.J.; Booms, B.; Tetrault, M. The service encounter: Diagnosing favourable and unfavourable incidents. J. Market. 1990, 54, 71-84.

57. Jones, M.; Suh, J. Transaction-specific satisfaction and overall satisfaction: And empirical analysis. J. Serv. Market. 2000, 14, 147-159. 
58. Holmes, J.H.; Lett, J.D. Product sampling and word-of-mouth. J. Advert. Res. 1977, 17, 35-40.

59. Swan, J.E.; Oliver, R.L. Post-purchase communications by consumers. J. Retail. 1989, 65, 516-533.

60. Brown, T.J.; Barry, T.E.; Dacin, P.A.; Gunst, R.F. Spreading the word: Investigating antecedents of consumers' positive word-of-mouth intentions and behaviors in a retailing context. J. Acad. Market. Sci. 2005, 33, 123-138.

61. Babin, B.J.; Lee, Y.K.; Kim, E.J.; Griffin, M. Modeling customer satisfaction and word-of-mouth: Restaurant patronage in Korea. J. Serv. Market. 2005, 19, 133-139.

62. Mooradian, T.; Olver, J. "I can't get no satisfaction:" The impact of personality and emotion on postpurchase processes. Psychol. Market. 1997, 14, 379-393.

63. Homburg, C.; Koschate, N.; Hoyer, W.D. Do satisfied customers really pay more? A study of the relationship between customer satisfaction and willingness to pay. J. Market. 2005, 69, 84-97.

64. Park, J.; Lee, K. The effects of corporate efforts for the sustainable management on the corporate trust and customer satisfaction. Asia-Pac. J. Bus. Commer. 2009, 1, 1-22.

65. Zhu, Q.; Sarkis, J.; Lai, K.H. Institutional-based antecedents and performance outcomes of internal and external green supply chain management practices. J. Purch. Supply Manag. 2013, 19, 106-117.

66. Hutchinson, J.; Lai, F.; Wang, Y. Understanding the relationships of quality, value, equity, satisfaction and behavioural intentions among golf travellers. Tour. Manag. 2009, 30, 298-308.

67. Ryu, K.; Lee, H.R.; Gon Kim, W. The influence of the quality of the physical environment, food, and service on restaurant image, customer perceived value, customer satisfaction, and behavioral intentions. Int. J. Contemp. Hosp. Manag. 2012, 24, 200-223.

68. Akamavi, R.K.; Mohamed, E.; Pellmann, K.; Xu, Y. Key determinants of passenger loyalty in the low-cost airline business. Tour. Manag. 2015, 46, 528-545.

69. Lee, J.S.; Hsu, L.T.; Han, H.; Kim, Y. Understanding how consumers view green hotels: How a hotel's green image can influence behavioural intentions. J. Sustain. Tour. 2010, 18, 901-914.

70. Hsiao, K.L. Why internet users are willing to pay for social networking services. Online Inf. Rev. 2011, 35, 770-788.

71. Attitudes, efficacy beliefs, and willingness to pay for environmental protection when travelling. Available online: http://thr.sagepub.com/content/early/2015/04/13/1467358415580360 (accessed on 9 July 2015).

72. Hsiao, K.L. Android Smartphone adoption and intention to pay for mobile Internet: Perspectives from software, hardware, design, and value. Library. Hi. Tech. 2013, 31, 216-235.

73. Anderson, J.C.; Gerbing, D.W. Structural equation modeling in practice: A review and recommended two-step approach. Psychol. Bull. 1988, 103, 411-423.

74. Bagozzi, R.P.; Yi, Y. On the evaluation of structural equation models. J. Acad. Market. Sci. 1988, 16, 74-94.

75. Bentler, P.M.; Bonett, D.G. Significance tests and goodness of fit in the analysis of covariance structures. Psychol. Bull. 1980, 88, 588-606.

76. Seyal, A.H.; Rahman, M.N.A.; Rahim, M.M. Determinants of academic use of the Internet: A structural equation model. Behav. Inf. Technol. 2002, 21, 71-86.

77. Hair, J.F.; Sarstedt, M.; Ringle, C.M.; Mena, J.A. An assessment of the use of partial least squares structural equation modeling in marketing research. J. Acad. Market. Sci. 2012, 40, 414-433. 
78. Kim, H.J. Relationships among servicescape, customer satisfaction, trust and loyalty-Focused on airline service. Korean J. Tour. Res. 2012, 27, 181-200.

79. Park, J. Passenger perceptions of service quality: Korean and Australian case studies. J. Air Transp. Manag. 2007, 13, 238-242.

80. Tsai, W.; Hsu, J. Corporate social responsibility programs choice and costs assessment in the airline industry-A hybrid model. J. Air Transp. Manag. 2008, 14, 188-196.

81. Chou, P.F.; Lu, C.S.; Chang, Y.H. Effects of service quality and customer satisfaction on customer loyalty in high-speed rail services in Taiwan. Transp. A: Transp. Sci. 2014, 10, 917-945.

82. Hussain, R.; Al Nasser, A.; Hussain, Y.K. Service quality and customer satisfaction of a UAE-based airline: An empirical investigation. J. Air Transp. Manag. 2015, 42, 167-175.

83. Kim, Y.K.; Lee, H.R. Customer satisfaction using low cost carriers. Tour. Manag. 2011, 32, 235-243.

84. Chang, D.; Chen, S.; Hsu, C.; Hu, A.H. Identifying strategic factors of the implantation CSR in the airline industry: The case of Asia-Pacific airlines. Sustainability 2015, 7, 7762-7783.

85. Mohr, L.A.; Webb, D.J.; Harris, K.E. Do consumers expect companies to be socially responsible? The impact of corporate social responsibility on buying behavior. J. Consum. Aff. 2001, 35, 45-72.

86. Park, E.; Kim, H.; Ohm, J.Y. Understanding driver adoption of car navigation systems using the extended technology acceptance model. Behav. Inf. Technol. 2015, 34, 741-751.

87. Park, E.; del Pobil, A.P. Technology acceptance model for the use of tablet PCs. Wirel. Pers. Commun. 2013, 73, 1561-1572.

88. Park, E.; del Pobil, A.P. Users' attitudes toward service robots in South Korea. Ind. Robot 2013, 40, 77-87.

89. Lee, S.; Park, E.; Kwon, S.J.; del Pobil, A.P. Antecedents of behavioral intention to use mobile telecommunication services: Effects of corporate social responsibility and technology acceptance. Sustainability 2015, 7, 11345-11359.

90. Chung, J.Y.; Whang, T. The impact of low cost carriers on Korean Island tourism. J. Transp. Geogr. 2011, 19, 1335-1340.

(C) 2015 by the authors; licensee MDPI, Basel, Switzerland. This article is an open access article distributed under the terms and conditions of the Creative Commons Attribution license (http://creativecommons.org/licenses/by/4.0/). 